\title{
IMPLIKASI ASAS RETROAKTIF TERHADAP KEABSAHAN AKTA NOTARIS/PPAT DALAM PEMBERIAN HAK GUNA BANGUNAN BAGI PERSEROAN TERBATAS
}

\author{
Oleh: \\ Made Gelgel $^{1}$
}

\begin{abstract}
Further and deeper research into the validity of the Retroactive Principle is required in order to provide assertiveness about the arrangement of Retroactive Principles in the field of agreement law in the Indonesian legal system, especially the Building Rights Agreement in Agrarian Law and the existence of obscure legal norms in the case of the legal Notary / PPAT to the granting right of building use for a period of validity is reviewed according to the provisions of Article 28 of Regulation of Head of National Land Agency Number 2 Year 2013 concerning the Delegation of Authority of Land Rights and Land Registration Activity and by using case approach of PT. Pan Pacific Nirwana Resort. This research is a normative legal research that is derived from the existence of obscurity of legal principle and legal norm contained in the provisions of Law Number 5 Year 1960 on Basic Agrarian Law Basic (UUPA) in the provisions of Article 30 and Article 28 Regulation of Head of National Land Agency No. 2 of 2013 on the Delegation of Authority of Land Rights and Land Registration Activities. The conclusion of this research in Agrarian Law there is legal uncertainty in the concept of law building rights agreement with a period of time that is still running and the future is approved by a new regulation by the government which caused the previous agreement to occur normatively contradictory whether using retroactive or non-retroactive principle and the validity of deed Notary / PPAT in the granting of right to building to limited liability company which is still valid time is reviewed according to UUPA, Article 28 Regulation of Head of National Land Agency Number 2 Year 2013 regarding Delegation of Authority of Land Rights and Land Registration Activity and Article 1320 Privat Law and by using approach case PT. Pan Pacific Nirwana Resort is not valid.
\end{abstract}

\section{Keywords: Implication of Retroactive Principle, Legality of Notary Deed / PPAT, Right of Building, Limited Liability Company.}

\begin{abstract}
Abstrak
Penelitian lebih lanjut dan mendalam terhadap keberlakuan Asas Retroaktif diperlukan dalam rangka memberikan ketegasan tentang pengaturan Asas Retroaktif di bidang hukum perjanjian dalam sistem hukum Indonesia khususnya perjanjian Hak Guna Bangunan dalam Hukum Agraria serta masih adanya kekaburan norma hukum dalam hal keabsahan akte Notaris/PPAT terhadap Perseroan Terbatas dalam pemberian Hak Guna Bangunan yang

1 Program Studi Magister Ilmu Hukum, Fakultas Hukum Universitas Udayana, Denpasar, Bali, email: gelgel.notarisppat@gmail.com
\end{abstract}


jangka waktunya masih berlaku dikaji menurut ketentuan Pasal 28 Peraturan Kepala Badan Pertanahan Nasional Nomor 2 Tahun 2013 tentang Pelimpahan Kewenangan Pemberian Hak Atas Tanah Dan Kegiatan Pendaftaran Tanah serta dengan menggunakan pendekatan kasus PT. Pan Pasific Nirwana Resort. Penelitian ini merupakan penelitian hukum normatif yakni beranjak dari adanya kekaburan asas hukum dan norma hukum yang terdapat di dalam ketentuan Undang-Undang Nomor 5 Tahun 1960 tentang Peraturan Dasar Pokok-pokok Agraria (UUPA) dalam ketentuan Pasal 30 dan Pasal 28 Peraturan Kepala Badan Pertanahan Nasional No. 2 Tahun 2013 tentang Pelimpahan Kewenangan Pemberian Hak Atas Tanah Dan Kegiatan Pendaftaran Tanah. Kesimpulan dari penelitian ini dalam Hukum Agraria terdapat ketidakpastian hukum dalam konsep hukum perjanjian Hak Guna Bangunan dengan jangka waktu yang masih berjalan dan ke depannya di sahkan suatu peraturan baru oleh pemerintah yang menyebabkan perjanjian sebelumnya terjadi pertentangan secara normatif apakah menggunakan asas retroaktif atau non retroaktif dan keabsahan Akta Notaris/ PPAT dalam Pemberian Hak Guna Bangunan terhadap Perseroan Terbatas yang jangka waktunya masih berlaku dikaji menurut UUPA, Pasal 28 Peraturan Kepala Badan Pertanahan Nasional Nomor 2 Tahun 2013 tentang Pelimpahan Kewenangan Pemberian Hak Atas Tanah Dan Kegiatan Pendaftaran Tanah jo Pasal 1320 KUH Perdata serta dengan menggunakan pendekatan kasus PT. Pan Pasific Nirwana Resort adalah tidak sah.

\section{Kata kunci: Implikasi Asas Retroaktif, Keabsahan Akta Notaris/PPAT, Hak Guna Bangunan, Perseroan Terbatas.}

\section{PENDAHULUAN}

Perkembangan kegiatan perniagaan yang semakin meningkat mengakibatkan peningkatan tuntutan masyarakat terhadap kepastian hukum serta pengembangan dunia usaha. Perkembangan ini mendorong kebutuhan pelayanan dari pejabat umum dalam bidang pembuatan alat bukti guna menjamin kepastian hukum tersebut. $^{2}$

Kegiatan perekonomian di bidang perniagaan ataupun properti dalam transaksi dengan jenis transaksi tertentu membutuhkan pelayanan dari pejabat umum dalam bidang

2 Herlien Budiono, 2013, Dasar Teknik Pembuatan Akta Notaris, Penerbit PT. Citra Aditya Bakti, Bandung, hlm. 1 pembuatan alat bukti guna menjamin kepastian hukum salah satunya adalah di bidang pertanahan. Contoh konkrit pelayanan dari pejabat umum yang berwenang sangat dibutuhkan adalah dalam hal jual beli terkait dengan pembuatan akta peralihan hak milik atas tanah atau pemberian Hak Guna Bangunan diatas tanah hak milik atau tanah negara. Bentuk perbuatan hukum ini harus dilakukan dengan menggunakan akta Pejabat Pembuat Akta Tanah (PPAT) serta bentuknya ditentukan oleh undang-undang agar memiliki nilai pembuktian yang otentik. $^{3}$

3 Maria S.W. Sumardjono, 2008, Tanah Dalam Perspektif Hak Ekonomi, Sosial, dan Budaya, PT. Kompas Media Nusantara, Jakarta, hlm.7 
Dalam melaksanakan tugas untuk membuat alat bukti mengenai perbuatan hukum tertentu mengenai hak atas tanah dan Hak Milik Atas Satuan Rumah Susun yang akan dijadikan dasar pendaftaran hak-hak atas tanah, tugas PPAT secara tegas diatur di dalam ketentuan Pasal 2 ayat (1) dan ayat (2) Peraturan Pemerintah Republik Indonesia Nomor 37 Tahun 1998 tentang Peraturan Jabatan Pejabat Pembuat Akta Tanah dinyatakan bahwa:

PPAT bertugas pokok melaksanakan sebagian kegiatan pendaftaran tanah dengan membuat akta sebagai bukti telah dilakukannya perbuatan hukum tertentu mengenai hak atas tanah atau Hak Milik Atas Satuan Rumah Susun, yang akan dijadikan dasar bagi pendaftaran perubahan data pendaftaran tanah yang diakibatkan oleh perbuatan hukum itu.

Perbuatan hukum sebagaimana dimaksud pada ayat (1) adalah sebagai berikut: jual beli, tukar menukar, hibah, pemasukan ke dalam perusahaan (inbreng), pembagian hak bersama, pemberian Hak Guna Bangunan/Hak Pakai atas Tanah Hak Milik, pemberian Hak Tanggungan, pemberian kuasa membebankan Hak Tanggungan.

Berkaitan dengan tugas PPAT dalam salah satu bentuk tugasnya adalah membuat akta pemberian Hak Guna Bangunan, penulis dalam penelitian ini menemukan adanya permasalahan hukum secara asas hukum dan normatif. Permasalahan yang terjadi dalam asas hukum adalah terkait dengan asas hukum perjanjian yang berlaku dalam sistem hukum Indonesia apakah menganut asas retroaktif atau tidak dalam hal suatu perjanjian Hak Guna Bangunan diatas tanah hak milik perorangan dengan Perseroan Terbatas yang telah dibuat, disepakati dan disahkan terlebih dahulu dan durasi perjanjiannya masih berjalan dan di kemudian hari muncul ketentuan peraturan baru dari pemerintahyangmenyatakanketentuan tersebut dinyatakan bertentangan dan tidak berlaku lagi.

Permasalahan normatif adalah terkait Hak Guna Bangunan. Secara normatif Hak Guna Bangunan diatur dalam ketentuan Pasal 35 UndangUndang No. 5 Tahun 1960 tentang Peraturan Dasar Pokok-Pokok Agraria (selanjutnya disebut UUPA) dijelaskan bahwa :

1. Hak Guna Bangunan adalah hak untuk mendirikan dan mempunyai bangunan-bangunan atas tanah yang bukan miliknya sendiri, dengan jangka waktu paling lama 30 tahun.

2. Atas permintaan pemegang hak dan dengan mengingat keperluan serta keadaan bangunanbangunannya, jangka waktu tersebut dalam ayat (1) dapat diperpanjang dengan waktu paling lama 20 tahun. 
3. Hak Guna Bangunan dapat beralih dan dialihkan kepada pihak lain.

Berdasarkan ketentuan pasal diatas jangka waktu Hak Guna Bangunan adalah 30 tahun dan kemudian dapat diperpanjang paling lama 20 tahun. Persoalan normatif muncul dalam penelitian ini setelah penulis mengkonkretisasikan melalui pendekatan kasus dengan mengambil fakta hukum yang terjadi dengan beranjak dari kasus penguasaan Hak Guna Bangunan oleh PT. Pan Pasific Nirwana Resort dengan luas 103 Hektar. ${ }^{4}$ Hal ini menunjukan adanya pertentangan secara normatif sejak disahkannya Peraturan Kepala Badan Pertanahan Nasional Nomor 2 Tahun 2013 tentang Pelimpahan Kewenangan Pemberian Hak Atas Tanah dan Pendaftaran Tanah (selanjutnya disebut Perkaban) berdasarkan pada ketentuan Pasal 4 dan Pasal 28 dengan mengaitkan terhadap akta pemberian Hak Guna Bangunan PT. Pan Pasific Nirwana Resort yang dibuat oleh PPAT dengan jangka waktunya masih berlaku hingga sekarang.

Secara lebih spesifik dan lebih lanjut dalam penelitian ini dilengkapi pula dengan pendekatan kasus untuk mempertegas persoalan hukum diatas dan lebih memperdalam kajian keilmuan yang penulis deskripsikan di bawah ini.

4 I Made Ardana Putra, 2003, Bagaimana Pariwisata Budaya Mendatang? (Artikel Balipost Edisi 2 Januari 2003), Data diunduh pada tanggal 19 Mei 2015 Pukul 14.30 Wita, avalaible from; URL; http://www.balipost. co.id/balipostcetak/2003/1/2/op2.html

\section{Kasus Posisi PT. Pan Pasific Nirwana Resort \\ PT. Pan Pacific Nirwana Resort} mendirikan hotel yang selanjutnya bernama Bali Nirwana Resort dan berlokasi di Tabanan. Hotel ini didirikan diatas lahan seluas 103 hektar dan telah menguasai ratusan hektar tanah rakyat yang sekaligus merangsek ke radius kesucian Pura Tanah Lot. Komponen pariwisata dan pengambil kebijakan di sektor pariwisata diminta segera menghentikan kegiatan mengorbankan pura sebagai objek wisata. Penggunaan fasilitas yang disucikan ini dinilai terdistorsi hanya untuk mencari keuntungan finansial tanpa mengindahkan kesakralan pura dan taksu Bali. Demikian terungkap dalam hasil rapat internal Komisi A DPRD Bali, Senin (23/12/2002). Komisi ini menyoroti kecenderungan pariwisata budaya yang kebablasan menjadi bisnis yang hanya berorientasi untuk menghasilkan uang saja. Jika ini dibiarkan terus, inilah awal yang dapat menghancurkan taksu tanah Bali.

Hotel Bali Nirwana Resort terletak di atas tebing curam yang menghadap ke samudera hindia dan Pura Tanah Lot serta menawarkan lapangan golf. Resort ini menyediakan kamar-kamar hunian yang mewah dan 5 kolam renang outdoor yang tersebar di area seluas 103 hektar. Resort juga menawarkan layanan antar-jemput terjadwal gratis ke daerah kuta dan seminyak hotel Bali Nirwana Resort berjarak hanya 200 
meter dari Nirwana Bali Golf Course, dan 45 menit berkendara dari Bandara Internasional Ngurah Rai dan terletak sejauh 500 meter dari Pura Tanah Lot yang indah. ${ }^{5}$

Dari kasus posisi diatas dengan melihat pada ketentuan Pasal 4 Perkaban Nomor 2 Tahun 2013 tentang Pelimpahan Kewenangan Pemberian Hak Atas Tanah dan Pendaftaran Tanah menetapkan secara tegas batasan luas tanah untuk pemberian Hak Guna Bangunan yang dapat dikuasai oleh Badan Hukum khususnya Perseroan Terbatas. Hal ini diatur dalam ketentuan Pasal 4 huruf (b) dinyatakan bahwa pemberian Hak Guna Bangunan untuk Badan Hukum atas tanah yang luasnya tidak lebih dari $20.000 \mathrm{M}^{2}$ (dua puluh ribu meter persegi) setara dengan 2 Hektar.

Ketentuan Pasal 28 Perkaban Nomor 2 Tahun 2013 tentang Pelimpahan Kewenangan Pemberian Hak Atas Tanah dan Pendaftaran Tanah menyatakan dengan tegas bahwa:

Pada saat peraturan ini mulai berlaku, maka Peraturan Kepala Badan Pertanahan Nasional Republik Indonesia Nomor 1 Tahun 2011 tentang Pelimpahan Kewenangan Pemberian Hak Atas Tanah dan Kegiatan Pendaftaran Tanah Tertentu sebagaimana telah diubah dengan Peraturan Kepala Badan Pertanahan Nasional Republik Indonesia Nomor 3

5 I Made Ardana Putra, 2003, Ibid
Tahun 2012 tentang Perubahan Atas Peraturan Kepala Badan Pertanahan Nasional Republik Indonesia Nomor 1 Tahun 2011 tentangPelimpahanKewenangan Pemberian Hak Atas Tanah dan Kegiatan Pendaftaran Tanah Tertentu dan peraturan yang bertentangan dengan Peraturan ini dicabut dan dinyatakan tidak berlaku lagi.

Perjanjian pemberian Hak Guna Bangunan oleh PT. Pan Pasific Nirwana Resort apabila dikaji secara spesifik kasus ini terjadi pada tahun 2002. Pasal 35 UUPA ayat (1) menyatakan bahwa hak guna bangunan adalah hak untuk mendirikan dan mempunyai bangunan-bangunan atas tanah yang bukan miliknya sendiri, dengan jangka waktu paling lama 30 tahun. Secara matematis berdasarkan penetapan jangka waktu 30 tahun oleh UUPA dalam pemberian Hak Guna Bangunan dengan pendekatan kasus PT. Pan Pasific Nirwana Resort hingga sekarang durasi perjanjian Hak Guna Bangunan tersebut masih berlangsung dan akan berakhir di tahun 2032 .

Hukum Perdata dalam kaitannya dengan perjanjian, tidak mengenal prinsip retroaktif (undang-undang berlaku surut) yang dimana perbuatan hukumnya terjadi terlebih dahulu kemudian baru disahkan peraturan terkait. Hal ini hanya dikenal dalam sistem Hukum Pidana dan khusus untuk kejahatan terorisme dan pelanggaran Hak Asasi Manusia (HAM) berat. 
Hak Guna Bangunan dari PT. Pan Pasific Nirwana Resort terletak diatas tanah seluas 103 Hektar. Secara otomatis objek perjanjian yang terdapat di dalam perjanjian Pemberian Hak Guna Bangunan PT. Pan Pasifik Nirwana Resort bertentangan dengan ketentuan Pasal 17 UUPA jo Pasal 4 dan Pasal 28 tentang Pelimpahan Kewenangan Pemberian Hak Atas Tanah dan Pendaftaran Tanah.

Pasal 4 jo Pasal 28 Perkaban juga tidak dijelaskan dan membahas tentang substansi keabsahan akta PPAT dalam pemberian Hak Guna Bangunan yang objek perjanjiannya melebihi batas luas tanah yang telah ditentukan oleh undang-undang dan jangka waktu perjanjiannya masih berlaku setelah Perkaban ini di sahkan.

Ketentuan Pasal 28 Perkaban dengan menginterpretasikan makna yang terkandung dalam ketentuan pasal tersebut dengan menggunakan penafsiran gramatikal (bahasa), substansi ketentuan pasal tersebut seakan-akan membatalkan pendaftaran tanah dalam pemberian Hak Guna Bangunan oleh PT. Pan Pasific Nirwana Resort yang telah dilakukan dengan menggunakan ketentuan peraturan perundang-undangan yang telah ada lebih dulu seperti Peraturan Pemerintah No. 24 Tahun 1997 tentang Pendaftaran Tanah jo Peraturan Pemerintah No. 37 Tahun 1998 tentang Peraturan Jabatan Pejabat Pembuat Akta Tanah apabila bertentangan dengan Perkaban ini.
Perkaban ini sebelum disahkannya pada tahun 2013 sebagai peraturan pelaksana dari UUPA, dalam ketentuan Pasal 17 UUPA menganut sistem pembatasan kepemilikan dan penguasaan tanah. Namun untuk pembatasan minimum dan maksimum luas tanah yang dapat dikuasai atau dimiliki oleh perseorangan atau badan hukum pengaturannya secara lengkap dan tegas baru ada pada tahun 2013. Hal ini tentunya akan memberikan dampak hukum bagi akta PPAT yang telah didaftarkan sebelum adanya perkaban ini dan jangka waktunya masih berlaku.

Berdasarkan pemaparan latar belakang diatas menarik bagi penulis untuk menulis judul penelitian tentang "Implikasi Asas Retroaktif Terhadap Keabsahan Akta Notaris/ PPAT Dalam Pemberian Hak Guna Bangunan Bagi Perseroan Terbatas"

Fokus rumusan masalah dari latar belakang diatas adalah

1. Bagaimanakah Implikasi asas retroaktif dalam hukum perjanjian, khususnya perjanjian pemberian hak guna bangunan dalam sistem hukum pertanahan yang berlaku di Indonesia menurut ketentuan UndangUndang Nomor 5 Tahun 1960 tentang Peraturan Dasar Pokokpokok Agraria (UUPA)?

2. Bagaimanakah keabsahan Akta Notaris/PPAT terhadap Perseroan Terbatas dalam 
pemberian Hak Guna Bangunan yang jangka waktunya masih berlaku dikaji menurut ketentuan Pasal 28 Peraturan Kepala Badan Pertanahan Nasional Nomor 2 Tahun 2013 tentang Pelimpahan Kewenangan Pemberian Hak Atas Tanah Dan Kegiatan Pendaftaran Tanah dan dengan pendekatan kasus PT. Pan Pasific Nirwana Resort? Originalitas penelitian yang mengungkapkan penelitian-penelitian terdahulu dalam penelitian ini sebagai berikut: pertama dari jurnal magister hukum udayana (udayana master law journal) berjudul pengawasan notaris oleh majelis pengawas notaris daerah pasca putusan M.K.NO.49/ PUU-X/2012 oleh dewa nyoman rai asmara putra ${ }^{6}$. Kedua dari jurnal dinamika hukum berjudul eksistensi hak pengelolaan atas tanah (HPL) dan realitas pembangunan Indonesia oleh elita rahmi. ${ }^{7}$ Perbedaan penelitian

6 ASMARA PUTRA, Dewa Nyoman Rai. PENGAWASAN NOTARIS OLEH MAJELIS PENGAWAS NOTARIS DAERAH PASCA PUTUSAN M.K.NO. 49/PUU-X/2012.Jurnal Magister Hukum Udayana (Udayana Master Law Journal), vol.5 no.4 edisi desember 2016. http://ojs.unud.ac.id/index.php/ jmhu/artocle/view/33077>. Diakses tanggal: 22 jan. 2017. doi: https://doi. org/10.24843/JMHU.2016.v05,i04.p11.

7 RAHMI, Elita. Eksistensi Hak Pengelolaan Atas Tanah (HPL) dan Realitas Pembangunan Indonesia. Jurnal Dinamika Hukum, vol.10 no.3 edisi september 2010. http://dinamikahukum. ini dari penelitian sebelumnya yaitu penelitian ini menganalisis implikasi retroaktif pemberian hak bangunan bagi perseroan terbatas.

Tujuan dari penelitian ini adalah Untukmendeskripsikan danmelakukan analisis secara komprehensif tentang Implikasi asas retroaktif dalam hukum perjanjian, khususnya perjanjian pemberian Hak Guna Bangunan dalam sistem hukum pertanahan yang berlaku di Indonesia menurut ketentuan Undang-Undang Nomor 5 Tahun 1960 tentang Peraturan Dasar Pokok-pokok Agraria (UUPA) dan keabsahan Akta Notaris/PPAT terhadap Perseroan Terbatas dalam pemberian Hak Guna Bangunan yang jangka waktunya masih berlaku dikaji menurut ketentuan Pasal 28 Peraturan Kepala Badan Pertanahan Nasional Nomor 2 Tahun 2013 tentang Pelimpahan Kewenangan Pemberian Hak Atas Tanah Dan Kegiatan Pendaftaran Tanah serta dengan pendekatan kasus PT. Pan Pasific Nirwana Resort.

\section{METODE PENELITIAN}

Penelitian ini menggunakan metode penelitian hukum normatif dengan beranjak dari adanya kekaburan asas hukum dan norma hukum. ${ }^{8}$

fh.unsoed.ac.id/index.php/JDH/article/ view/104>. Diskes tanggal 22 jan. 2017. doi: http://dx.doi.org/10.20884/1. jdh.2010.10.3.104

8 Jhony Ibrahim, 2005, Teori \& Metodelogi Penelitian Hukum Normatif' Surabaya, hlm. 284 
Pendekatan dalam penelitian ini menggunakan pendekatan perundangundangan, pendekatan analisis konsep hukum dan pendekatan kasus. Bahan hukum yang digunakan terdiri dari bahan hukum primer, bahan hukum sekunder, dan bahan hukum tersier.

III. HASIL DAN PEMBAHASAN

3.1 Implikasi Asas Retroaktif Dalam Hukum Perjanjian, Khususnya Perjanjian

Pemberian Hak Guna Bangunan Dalam Sistem Hukum Pertanahan Yang Berlaku Di Indonesia Menurut Ketentuan Undang-Undang Nomor 5 Tahun 1960 Tentang Peraturan Dasar Pokok-Pokok Agraria (UUPA).

Indonesia adalah Negara Hukum dimana setiap warga negara yang tinggal di Indonesia wajib mentaati hukum yang berlaku. Hukum perjanjian diatur dalam ketentuan Pasal 1331 Kitab Undang-Undang Hukum Perdata Indonesia.

Hukum perjanjian yang terdapat di Indonesia dijelaskan bahwa perjanjian atau kontrak merupakan suatu peristiwa di mana dua belah pihak saling berjanji untuk melaksanakan suatu hal dan perjanjian itu berlaku sebagai suatu undang-undang bagi pihak yang saling mengikatkan diri dalam perjanjian, serta mengakibatkan timbulnya suatu hubungan antara dua pihak tersebut yang dinamakan perikatan. Perjanjian itu menerbitkan suatu perikatan antara dua orang atau dua pihak yang membuatnya. Perjanjian dalam bentuknya dapat berupa suatu rangkaian perkataan yang mengandung janji-janji atau kesanggupan yang diucapkan atau ditulis.

Hukum Perdata dalam konsepkonsepnya terkait dengan hukum perjanjian tidak dijelaskan atau mengenal prinsip retroaktif (udangundang berlaku surut). Asas Retroaktif adalah pemberlakuan suatu undangundang setelah terjadinya peristiwa hukum. Hal ini juga terjadi kesamaan dengan perjanjian pemberian Hak Guna Bangunan yang terdapat di dalam ketentuan UUPA yang tidak memberikan penjelasan secara tegas tentang status hukum Asas Retroaktif dalam perjanjian di bidang pertanahan secara spesifik.

Asas Retroaktif hanya dikenal dalam sistem Hukum Pidana khususnya berkaitan dengan kasus terorisme dan pelanggaran HAM berat (extra ordinary crime). Asas Retroaktif pemberlakuannya pada Hukum Pidana Indonesia hanya bisa diterapkan pada Hukum Pidana Materiil dan Asas Retroaktif tidak bisa diberlakukan pada Hukum Pidana Formil secara umum namun dapat diberlakukan Pada Hukum Pidana Formil secara khusus. ${ }^{9}$

Asas hukum secara teoritis dapat

9 CAHYA WIDYANTARA, Pande I Putu; SRI INDRAWATI, Anak Agung. PEMBERLAKUAN ASAS RETROAKTIF DALAM HUKUM PIDANA INDONESIA. Kertha Wicara, vol.5 no. 2 edisi juni 2015.<http://ojs.unud.ac.id/index.php/kerthawicara/ article/view/14330> 
dibedakan menjadi dua:

1. Asas Hukum Konstitutif adalah asas yang harus ada dalam suatu sistem hukum dan tanpa eksistensinya sesuatu tidak merupakan norma hukum.

2. Asas Hukum Regulatif adalah asas ini diperlukan untuk dapat berprosesnya sistem hukum, tanpa eksistensinya maka hukum akan menghasilkan ketidakadilan. ${ }^{10}$

Asas Hukum Konstitutif merupakan representasi dari asas legalitas dan jangka waktu perjanjian Hak Guna Bangunan telah diatur di dalam ketentuan Pasal 35 ayat (1) UUPA. Asas Hukum Regulatif ini oleh peneliti belum terdapat kejelasan dalam hukum perjanjian, khususnya perjanjian pemberian hak guna bangunan dalam sistem hukum pertanahan yang berlaku di indonesia menurut ketentuan undang-undang nomor 5 tahun 1960 tentang Peraturan Dasar Pokok-Pokok Agraria.

Dalam hukum perdata dan sistem hukum pertanahan yang berlaku di Indonesia ke depan hendaknya memberikan ketegasan dan kepastian hukum terkait dengan perjanjianperjanjian di bidang pertanahan yang di dalamnya memiliki durasi waktu berlakunya suatu perjanjian dan di kemudian hari disahkan ketentuan peraturan yang baru tentang

10 Soerjono Soekanto dan Sri Mamudji, 2011, Penelitian Hukum Normatif Suatu Tinjauan Singkat, PT. Raja Grafindo Persada, Jakarta, hlm.68 keberadaan perjanjian yang dibuat sebelumnya apakah menggunakan asas retroaktif atau tidak dalam hal adanya pertentangan setelah timbulnya aturan baru yang disahkan.

3.2. Keabsahan Akta Notaris/ PPAT Terhadap Perseroan Terbatas Dalam Pemberian Hak Guna Bangunan Yang Jangka Waktunya Masih Berlaku Dikaji Menurut Ketentuan Pasal 28 Peraturan Kepala Badan Pertanahan Nasional Nomor 2 Tahun 2013 Tentang Pelimpahan Kewenangan Pemberian Hak Atas Tanah Dan Kegiatan Pendaftaran Tanah Serta Dengan Pendekatan Kasus PT. Pan Pasific Nirwana Resort.

Ketentuan Undang-Undang Republik Indonesia Nomor 12 Tahun 2011 tentang Pembentukan Peraturan Perundang-Undangan dalam Pasal 8 ayat (1) dinyatakan bahwa :

Jenis peraturan perundangundangan selain sebagaimana dimaksud dalam Pasal 7 ayat (1) mencakup peraturan yang ditetapkan oleh Majelis Permusyawaratan Rakyat, Dewan Perwakilan Rakyat, Dewan Perwakilan Daerah, Mahkamah Agung, Mahkamah Konstitusi, Badan Pemeriksa Keuangan, Komisi Yudisial, Bank Indonesia, Menteri, badan, lembaga, atau komisi yang setingkat yang dibentuk dengan 
Undang-UndangatauPemerintah atas perintah Undang-Undang, Dewan Perwakilan Rakyat Daerah Provinsi, Gubernur, Dewan Perwakilan Rakyat Daerah Kabupaten/Kota, Bupati/ Walikota, Kepala Desa atau yang setingkat.

Dalam penjelasan pasal demi pasal ketentuan Pasal 8 ayat (1) dinyatakan bahwa yang dimaksud dengan "Peraturan Menteri" adalah peraturan yang ditetapkan oleh menteri berdasarkanmaterimuatan dalam rangka penyelenggaraan urusan tertentu dalam pemerintahan.

Berdasarkan substansi dalam ketentuan Pasal 8 diatas penulis berpandangan bahwa Peraturan Kepala Badan Pertanahan Nasional Nomor 2 Tahun 2013 tentang Pelimpahan Kewenangan Pemberian Hak Atas Tanah Dan Kegiatan Pendaftaran Tanah adalah sah sebagai peraturan perundang-undangan dalam sistem hukum yang berlaku di Indonesia.

Sejak disahkannya Peraturan Kepala Badan Pertanahan Nasional Nomor 2 Tahun 2013 tentang Pelimpahan Kewenangan Pemberian Hak Atas Tanah Dan Kegiatan Pendaftaran Tanah dalam ketentuan Pasal 28 dinyatakan secara tegas bahwa :

Pada saat peraturan ini mulai berlaku, maka Peraturan Kepala Badan Pertanahan Nasional
Republik Indonesia Nomor 1 Tahun 2011 tentang Pelimpahan Kewenangan Pemberian Hak Atas Tanah dan Kegiatan Pendaftaran Tanah Tertentu sebagaimana telah diubah dengan Peraturan Kepala Badan Pertanahan Nasional Republik Indonesia Nomor 3 Tahun 2012 tentang Perubahan Atas Peraturan Kepala Badan Pertanahan Nasional Republik Indonesia Nomor 1 Tahun 2011 tentangPelimpahanKewenangan Pemberian Hak Atas Tanah dan Kegiatan Pendaftaran Tanah Tertentu dan peraturan yang bertentangan dengan Peraturan ini dicabut dan dinyatakan tidak berlaku lagi.

Penjelasan pasal demi pasal ketentuan Pasal 28 Perkaban ini adalah cukup jelas.

Penulis berpandangan terkait dengan makna yang terdapat di dalam ketentuan Pasal 28 Perkaban diatas masih terjadi kekaburan norma hukum dengan tidak dijelaskannya tentang keabsahan akta PPAT dalam pemberian Hak Guna Bangunan yang boyak perjanjiannya melebihi batas luas tanah yang telah ditentukan oleh undang-undang dan jangka waktu perjanjiannya masih berlaku setelah Perkaban ini di sahkan.

Ketentuan Pasal 28 Perkaban diatas dengan menginterpretasikan makna yang terkandung dalam 
ketentuan pasal tersebut dengan penafsiran gramatikal (bahasa), substansi ketentuan pasal diatas seakan-akan membatalkan pendaftaran tanah terkait pemberian Hak Guna Bangunan diatas tanah seluas 103 Hektar dengan pemegang hak PT. Pan Pasific Nirwana Resort yang telah dilakukan dengan menggunakan ketentuan peraturan perundangundangan yang telah ada lebih dulu seperti Peraturan Pemerintah No. 24 Tahun 1997 tentang Pendaftaran Tanah jo Peraturan Pemerintah No. 37 Tahun 1998 tentang Peraturan Jabatan Pejabat Pembuat Akta Tanah apabila bertentangan dengan Perkaban ini. Pasal 4 Perkaban Nomor 2 Tahun 2013 tentang Pelimpahan Kewenangan Pemberian Hak Atas Tanah dan Pendaftaran Tanah menetapkan secara tegas batasan luas tanah untuk pemberian Hak Guna Bangunan yang dapat dikuasai oleh Badan Hukum dalam hal ini Perseroan Terbatas. Hal ini diatur dalam ketentuan Pasal 4 huruf (b) dinyatakan bahwa pemberian Hak Guna Bangunan untuk badan hukum atas tanah yang luasnya tidak lebih dari $20.000 \mathrm{M}^{2}$ (dua puluh ribu meter persegi) setara dengan 2 Hektar.

Pembentukan norma dalam suatu aturan peraturan perundang-undangan hendaknya memberikan jaminan kepastian hukum, kemanfaatan, dan keadilan. Menurut Teori Kepastian Hukum dari Utrecht yang penulis gunakan untuk mengkaji permasalahan dalam penelitian ini, dijelaskan bahwa teori kepastian hukum memiliki 2 (dua) substansi penting. Substansi yang pertama adalah adanya ketentuan/ aturan yang bersifat umum dapat memberikan pemahaman kepada subjek hukum untuk mengetahui perbuatan apa yang boleh atau tidak boleh dilakukan. Substansi yang kedua adalah merupakan jaminan perlindungan hukum bagi subjek hukum dari kesewenang-wenangan tindakan pemerintah. Dengan adanya aturan hukum yang bersifat umum itu subjek hukum dapat mengetahui dan memahami terkait dengan halhal apa saja yang dapat dibebankan atau dilakukan Negara terhadapnya. Kepastian hukum bukan hanya berupa pasal-pasal dalam undang-undang melainkan juga adanya konsistensi dalam putusan hakim antara putusan hakim yang satu dengan putusan hakim lainnya untuk kasus yang serupa yang telah di putuskan. ${ }^{11}$

Pasal 28 ketentuan Peraturan Kepala Badan Pertanahan Nasional Nomor 2 Tahun 2013 tentang Pelimpahan Kewenangan Pemberian Hak Atas Tanah Dan Kegiatan Pendaftaran Tanah belum memberikan adanya kepastian hukum dalam hal perjanjian pemberian Hak Guna Bangunan dengan pemegang hak PT. Pan Pasific Nirwana Resort yang jangka waktunya masih berlaku sejak peraturan ini disahkan.

Kepastian hukum merupakan

11 Peter Mahmud Marzuki, 2008, Pengantar Ilmu Hukum, Kencana Pranada Media Group, Jakarta, hlm.158 
hal yang sangat penting. Dengan mengelaborasi teori hukum diatas penulis berpandangan bahwa adanya ketentuan/aturan yang bersifat umum dapat memberikan pemahaman kepada subjek hukum yang terdiri dari orang atau badan hukum untuk mengetahui perbuatan apa yang boleh atau tidak boleh dilakukan serta merupakan jaminan perlindungan hukum bagi subjek hukum dari kesewenangwenangan tindakan pemerintah. Perkaban ini tidak mencakup tentang lingkup kewenangan PPAT dalam tugasnya melakukan kegiatan pendaftaran tanah salah satunya adalah Hak Guna Bangunan dengan Akta Pemberian Hak Guna Bangunan.

Keabsahan Akta Notaris/PPAT dalam Pemberian Hak Guna Bangunan terhadap PT. Pan Pasific Nirwana Resort diatas tanah seluas 103 hektar yang jangka waktunya masih berlaku dikaji menurut ketentuan Pasal 4, Pasal 28 Peraturan Kepala Badan Pertanahan Nasional Nomor 2 Tahun 2013 tentang Pelimpahan Kewenangan Pemberian Hak Atas Tanah Dan Kegiatan Pendaftaran Tanah jo Pasal 1320 KUH Perdata adalah tidak sah. Pasal 1320 menyatakan bahwa ada empat syarat yang harus dipenuhi untuk tercapainya persetujuan yang sah yaitu:

a. Kesepakatan mereka yang mengikatkan dirinya;

b. Kecakapan untuk membuat suatu perikatan;

c. Suatu pokok persoalan tertentu; d. Suatu sebab yang tidak terlarang.

Akta pemberian Hak Gunan Bangunan dalam kasus Pan Pasific Nirwana Resort bertentangan dengan ketentuan Pasal 1320 KUH Perdata tentang sarat sahnya perjanjian yakni suatu sebab yang tidak terlarang. Suatu perjanjian harus memenuhi syarat subjektif dan sarat obyektif. Syarat subjektif tidak terpenuhi maka akibat hukum perjanjian adalah dapat dibatalkan (vernietigbar). Syarat objektif tidak terpenuhi maka akibat hukum perjanjian adalah batal demi hukum (nietig). ${ }^{12}$

Objek perjanjian Hak Guna Bangunan dengan pemegang hak PT. Pan Pasific Nirwana Resort seluas 103 Hektar. Hal ini secara tegas bertentangan dengan ketentuan Pasal 4 huruf (b) Peraturan Kepala Badan Pertanahan Nasional Nomor 2 Tahun 2013 tentang Pelimpahan Kewenangan Pemberian Hak Atas Tanah Dan Kegiatan Pendaftaran Tanah dinyatakan bahwa pemberian Hak Guna Bangunan untuk badan hukum atas tanah yang luasnya tidak lebih dari $20.000 \mathrm{M}^{2}$ (dua puluh ribu meter persegi) setara dengan 2 Hektar. Akibat hukum dari perjanjian ini adalah batal demi hukum karena tidak terpenuhinya syarat objektif yakni suatu sebab yang tidak terlarang atau bertentangan dengan undang-undang. Dengan demikian perjanjian dianggap

12 Habib Adjie, 2011, Kebatalan dan Pembatalan Akta Notaris, PT. Refika Aditama Bandung, hlm..65 
tidak pernah ada dan tidak mengikat siapapun.

\section{KESIMPULAN}

1. Implikasi asas retroaktif terhadap perjanjian pemberian hak guna bangunan dalam sistem hukum pertanahan di Indonesia menurut ketentuan UndangUndang Nomor 5 Tahun 1960 tentang Peraturan Dasar PokokPokok Agraria (UUPA) adalah terdapat ketidakpastian hukum dalam konsep hukum perjanjian Hak Guna Bangunan dengan jangka waktu masih berjalan dan ke depannya di sahkan suatu peraturan baru oleh pemerintah yang menyebabkan perjanjian sebelumnya terjadi pertentangan secara normatif apakah menggunakan asas retroaktif atau non retroaktif.

2. Keabsahan Akta Notaris/PPAT dalam Pemberian Hak Guna Bangunan terhadap Badan Hukum Privat yang jangka waktunya masih berlaku dikaji menurut ketentuan Pasal 28 Peraturan Kepala Badan Pertanahan Nasional Nomor 2 Tahun 2013 tentang Pelimpahan Kewenangan Pemberian Hak Atas Tanah Dan Kegiatan Pendaftaran Tanah jo Pasal 1320 KUH Perdata serta dengan menggunakan pendekatan kasus PT. Pan Pasific Nirwana Resort adalah tidak sah. Akta pemberian
Hak Gunan Bangunan dalam kasus PT. Pan Pasific Nirwana Resort bertentangan dengan ketentuan Pasal 1320 tentang sarat sahnya perjanjian tentang suatu sebab yang dilarang. Objek perjanjian Hak Guna Bangunan dengan pemegang hak PT. Pan Pasific Nirwana Resort seluas 103 Hektar. Hal ini secara tegas bertentangan dengan ketentuan Pasal 4 huruf (b) Peraturan Kepala Badan Pertanahan Nasional Nomor 2 Tahun 2013 tentang Pelimpahan Kewenangan Pemberian Hak Atas Tanah Dan Kegiatan Pendaftaran Tanah dinyatakan bahwa pemberian Hak Guna Bangunan untuk badan hukum atas tanah yang luasnya tidak lebih dari $20.000 \mathrm{M}^{2}$ (dua puluh ribu meter persegi) setara dengan 2 Hektar. Akibat hukum dari perjanjian ini adalah batal demi hukum karena tidak terpenuhinya syarat objektif yakni suatu sebab yang tidak bertentangan dengan ketentuan undang-undang. Dengan demikian perjanjian dianggap tidak pernah ada dan tidak mengikat siapapun.

\section{DAFTAR PUSTAKA}


Buku

Adjie, Habib, 2011, Kebatalan dan

Pembatalan Akta Notaris, PT.

Refika Aditama Bandung.

Budiono, Herlien, 2013, Dasar Teknik

Pembuatan Akta Notaris,

Penerbit PT. Citra Aditya Bakti,

Bandung.

Ibrahim, Jhony, 2005, Teori \& Metodelogi Penelitian Hukum

Normatif, Surabaya.

Jhony Ibrahim, 2005, Teori \&

Metodelogi Penelitian Hukum

Normatif' Surabaya.

Marzuki, Peter Mahmud, 2008,

Pengantar Ilmu Hukum, Kencana

Pranada Media Group, Jakarta.

Sumardjono, Maria S.W., 2008, Tanah

Dalam Perspektif Hak Ekonomi,

Sosial, dan Budaya, PT. Kompas

Media Nusantara, Jakarta.

Soekanto, Soerjono dan Sri Mamudji,

2011,PenelitianHukumNormatif

Suatu Tinjauan Singkat, PT. Raja

Grafindo Persada, Jakarta.

\section{Jurnal}

ASMARA PUTRA, Dewa Nyoman Rai.PENGAWASANNOTARIS OLEH MAJELIS PENGAWAS NOTARIS DAERAH PASCA PUTUSAN M.K.NO. 49/PUU$\mathrm{X} / 2012$.Jurnal Magister Hukum Udayana (Udayana Master Law Journal), vol.5 no.4 edisi desember 2016. http:// ojs.unud.ac.id/index.php/jmhu/ artocle/view/33077>. Diakses tanggal: 22 jan. 2017. doi: https://
doi.org/10.24843/JMHU.2016. v05,i04.p11.

CAHYA WIDYANTARA, Pande I Putu; SRI INDRAWATI, Anak Agung. PEMBERLAKUAN ASAS RETROAKTIF DALAM HUKUM PIDANA INDONESIA. Kertha Wicara, vol.5 no.2 edisi juni 2015. $<$ http://ojs.unud.ac.id/index. php/kerthawicara/article/view/ 14330>Diakses tanggal: 22 jan. 2017.

RAHMI, Elita. Eksistensi Hak Pengelolaan Atas Tanah (HPL) dan Realitas Pembangunan Indonesia. Jurnal Dinamika Hukum, vol.10 no.3 edisi september 2010. http:// dinamikahukum.fh.unsoed. ac.id/index.php/JDH/article/ view/104>. Diskes tanggal 22 jan. 2017. doi: http:// dx.doi .org/10.20884/1. jdh.2010.10.3.104

\section{Internet}

I Made Ardana Putra, 2003, Bagaimana Pariwisata Budaya Mendatang ? (Artikel Balipost Edisi 2 Januari 2003), Data diunduh pada tanggal 19 Mei 2015 Pukul 14.30 Wita, avalaible from;URL;http://www.balipost. co.id/balipostcetak/2003/1/2/ op2.htm.

\section{Peraturan Perundang-undangan}


Undang-Undang No. 5 Tahun 1960 tentang Peraturan Dasar PokokPokok Agraria Lembaran Negara Republik Indonesia Tahun 1960 Nomor 104

Peraturan Kepala Badan Pertanahan Nasional No. 2 Tahun 2013 tentang PelimpahanKewenangan Pemberian Hak Atas Tanah Dan Kegiatan Pendafataran Tanah Berita Negara Republik Indonesia Tahun 2013 Nomor 107. 